\title{
Typhoid fever: current and future control approaches
}

Bernard Ivanoff

\begin{abstract}
Abstrak
Biasanya pencegahan penyakit enterik mencakup sanitasi dasar dan kebersihan pribadi, yang meliputi pemurnian air, memperbaiki penyaluran air dan pengendalian limbah, penyediaan fasilitas cuci tangan, pembangunan dan pemakaian WC, merebus air, serta pengawasan penyedia makanan. Walaupun demikian, seringkali sulit untuk secara sempurna menerapkan rekomendasi ini. Terapi antibiotika adalah suatu sukses untuk pengelolaan demam tifoid untuk beberapa waktu. Sayang sekali sejak 1990 semakin banyak ditemukan galur S. typhi yang resisten terhadap kebanyakan antibiotika yang sebelumnya bermanfaat. Kenyataannya, meskipun pada kondisi optimal, gabungan dari intervensi yang ada (pendidikan kesehatan dan pemberian antibiotika) tampaknya tidak akan dapat menyelesaikan masalah ini secara tuntas. Hal ini berarti bahwa diperlukan suatu intervensi kesehatan tambahan yang efektif untuk mengendalikan demam tifoid. Vaksin yang aman dan efektif saat ini sudah tersedia. Vaksin ini digunakan oleh wisatawan, tetapi dapat pula digunakan, pada kondisi yang sesuai, secara rutin sebagai pelengkap perangkat kesehatan masyarakat di negara berkembang untuk mengendalikan demam tifoid.
\end{abstract}

\begin{abstract}
Usually the prevention of enteric diseases comprises basic sanitary and hygiene measures including purifying water supplies, improving water delivery and sewage control, supplying handwashing washing facilities, construction and use of latrines, boiling water and supervising foodhandlers. Most of the time, however, it is difficult to properly apply these recommendations. Antibiotic therapy has been for many time a successful control measure in the clinical management of typhoid fever. Unfortunately since 1990 there are more and more strains of S. typhi that are resistant to most previously useful oral antibiotics. Actually even in optimal conditions the existing mix of interventions (health education and antibiotics treatment) is unlikely to eliminate completely the problem. It means that there is a need for an effective complementary health intervention to control typhoid fever. Safe and effective vaccines are currently available. They are used by travelers but could also be used, in appropriate conditions, routinely as a complementary public health tools in developing countries which need to control typhoid fever.
\end{abstract}

Diarrhoeal disease are still responsible for about 3 million deaths each year, of which an estimated 600,000 deaths are caused by typhoid fever (TF). Prevention of enteric diseases comprises basic sanitary and hygiene measures including purifying water supplies, improving water delivery and sewage control, supplying handwashing facilities, construction and use of latrines, boiling water and supervising foodhandlers ${ }^{4}$. Most of the time, however, it is difficult to properly apply these recommendations. Antibiotic therapy has been for many years a successful control measure in that clinical management of typhoid fever particularly oral chloramphenicol which was highly effective in treating acute $\mathrm{TF}^{l}$. However, since circa 1990, there have emerged strains of S.typhi that are resistant to most previously useful oral antibiotics 2,3 . The antimicrobials that remain effective are relatively expensive (e.g. oral floroquinolones) and some must be administered parenterally (e.g. cefiriaxone), there by posing quandary for developing countries. The emergence of the strains resistant to

WHO / VRD Geneva Switzerland multiple antibiotics and their wide dissemination throughout the Middle East South and Southeast Asia and Northeast Africa constitutes a pivotal chapter in the history of typhoid fever, the consequenees of which are only beginning to unravel2,3,5-8. The dilemma posed by the emergence, spread and epidemiologic persistence of the multiply antibioticresistant S.typhi strains provides a propitious moment to consider the global problem of typhoid fever, including the therapeutic and public health challenges posed by this disease and to find future adapted control measure. Actually even in the optimal conditions the existing mix of interventions (health education and antibiotic treament) is unlikely to eliminate completely the problem. There is a need for an effective, complementary, health intervention to control TF. Could vaccination be the answer?

Two effective vaccines, injectable Vi polysaccharide and oral Ty 21 a, have already been licensed. These vaccines are currently used for travelers but could also be used, in appropriate conditions, routinely as a complementary public health tool in developing countries or for controlling TF in outbreak situation. 
The primary target population for the use of TF vaccines would be school-age children or infants in developing countries 10 . For routine vaccination programmes, school-based vaccination (Vi or Ty21a) may be appropriate in some areas, whereas the limited attendance at school may make incorporation of typhoid vaccination into the current FPI schedule most desirable in other areas. The decision to incorporate vaccination against typhoid into a country's immunization programme should ideally be based on careful consideration of the local epidemiology of typhoid, including age-specific incidence and subpopulation at particularly high risk, as well as quantitative analysis of the costs and benefits of the typhoid vaccine to be included as a public health tool 9 . More information is required about the immunogenicity and safety of these vaccines when administered to infants at the age scheduled for DTP (Vi conjugate vaccine, or one oral dose TP vaccine), or measles vaccine (Vi, or one oral dose vaccine). Such studies should not only evaluate immune responses to each vaccine at this age, when compared to administration at an older age (e.g. 24 months), but should also assess whether administration of typhoid vaccines interferes with responses to simultaneously administered vaccines.

In conclusion, several epidemiological questions beg to be answered. The first involves quantifying in a more precise manner the global burden of TF. The second concerns quantifying the incidence of bacteremic disease in infants and toddlers less than two years or age. However, this should not postpone the decision to use vaccines against TF. Actually, we know, today, that TF is an important problem, we just need to have more precise data ; and we know that the currently available vaccines are effective in children more than two years old, and appropriate for use in countries where the target population is school children. In countries where the incidence is found to be earlier, in infants and toddler, the use of a conjugate $\mathrm{Vi}$ vaccine or one oral live vaccine should be considered. A satisfactory rest to replace bacteriologic culture remains a desirable goal. Finally there is a need for evaluation of TF vaccines in outbreak situations, for which no data exist. It would help public health authorities to take appropriate action in such a situation.

\section{REFERENCES}

1. Woodward TE, Smadel JE, Ley HL, Green R, Mankakan DS. Preliminary report on the beneficial effect of of choloromycetin in the treatment of typhoid fever. Ann Inter Med 1948; 29: $131-4$

2. Gupta A. Multidrug-resistant typhoid fever in children: epidemiology and therapeutic approach. Pediatr Infect Dis 1994; 13: 124-40.

3. Bhutta ZA, Naqvi SH, Razzaq RA, Farooqui BJ. Multidrugresistant typhoid in children: presentation and clinical features. Rev Infect Dis 1991; 13: 832-6.

4. Wolman A, Gorman A. The significance of waterborne typhoid fever outbreaks. Baltimore Williams \& Wilkins 1931.

5. Rowe B, Ward LR, Threlfall EI. Spread of multiresistant Sal monella typhi. Lancet 1990; 336: 1065-6

6. Mikhail IA, Hurberberger RL, Farid Z, Girgis NL, Woody JN. Antibiotic-multiresistant Salmonella typhi in Egypt. Trans R Soc Trop Med Hyg 1989; 83: 120

7. Anand AC, Kataria VK, Singh W, Chatterjee SD. Epidemic multiresistant enteric fever in eastern India [letter]. Lancet 1990; 335: 352.

8. Nguyen TA, Ha Ba K, Nguyen TD. [Typhoid fever in South Vietnam, 1990-1993]. Bull Soc Pathot Exot 1993; 86: 476-8.

9. Ivanoff B, Levine MM, Lambert PH. Vaccination against typhoid fever: present status. Bull Wld Hlth Org 1994; 72: 95771.

10. Ferrecio C, Levine MM, Rodriguez H, Contréas R. Comparative efficacy of two, three, or four doses of Ty21a live oral typhoid vaccine in enteric- coated capsules: a field trail in an endemic aren. J Infect Dis 1989; 159: 766-9. 